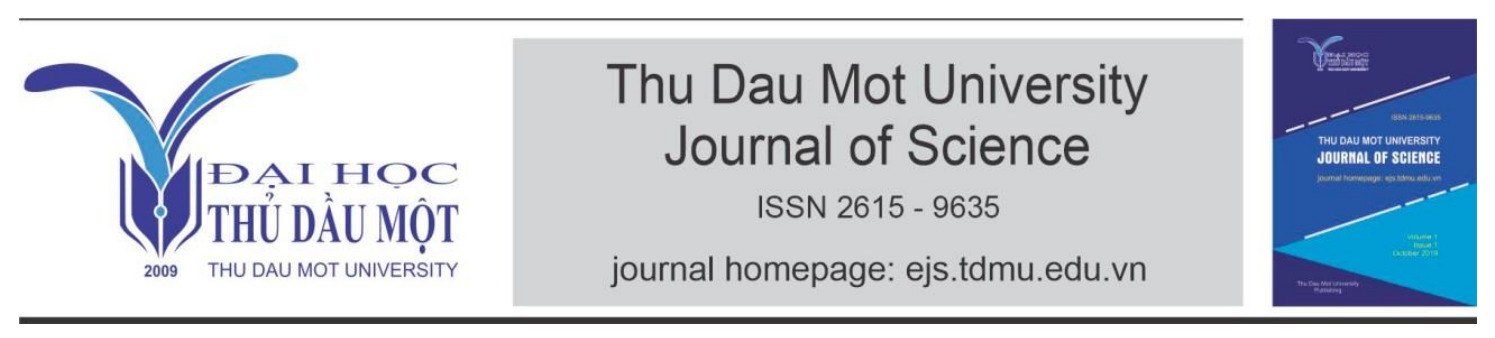

\title{
The followers of Caodaism in foreign countries and the administrative relation between believers of Caodaism in foreign countries and Cao Dai church in country
}

By Huynh Ngoc Thu, Le Thi My Ha (University of Social Sciences and Humanities - Viet Nam National University - Ho Chi Minh City)

Article Info: $\quad$ Received 18 Oct 2020, Accepted 25 Nov 2020, Available online 15 Dec, 2020 Corresponding author: hnthu76@hcmussh.edu.vn

https://doi.org/10.37550/tdmu.EJS/2020.04.089

\begin{abstract}
Caodaism was established in the South in 1926. It has been considered as one of indigenous religions in Vietnam in the first half of 20th century. In the first days, trend of Caodaism was to develop in foreign countries through missionary campaigns. Cao Dai's dignitaries carried out missionary task in Cambodia, France, German, China... That was why followers of Cao Dai (Cao Dai followers) lived in these countries in the early 1930s. After 1975 many people in the South emigrated to America, Australia. Many of them were Cao Dai followers. After their lives have been stabilized, they have gathered to build temples so Caodaism in foreign countries has developed strongly. The number of believers in foreign countries is about 50,000 believers. They have created connection with Cao Dai sects through many forms. In this article we mention three main contents: 1) Cao Dai followers in foreign countries: the process of establishment and development after 1975; 2) The administrative relation between Cao Dai followers in foreign countries and Cao Dai church in Vietnam; 3) Some remarks on the administrative relation. The information in this article has been completed with two research methods: in-depth interview and participate observation.
\end{abstract}

Keywords: administrative relation, political system, national culture 


\section{Introduction}

Caodaism was established in 1926 in the South of Vietnam. This is considered one of the indigenous religions founded by Vietnamese people. This religion expresses a mixed philosophy with the thought of three religions (Buddhism, Taoism and Confucianism), called "Tam giáo qui nguyên", and "ngũ chi hiệp nhất" (five religions in Cao Đài: Buddhism, Taoism, Christianity, Confucianism, Geniism). This religion is also called "The Great Way of The Third Amnesty Era" (Đại Đạo Tam Kỳ Phổ Độ). From the first year of formation, the number of followers of Cao Dai reached 50,000 (1926). This number continued to increase fast. From 1928 to 1935, the number Cao Dai followers were nearly one million and over 2 million in recent years (Thu \& Tai, 2019, 58-60).

After 1975, a part of Vietnamese people emigrated to many foreign countries such as America, Australia, Canada, France... According to statistical data of Robinson W. Courtland, from 1980 to 1997, 623.509 people established permanent abode in foreign countries (Robison, W. Courtland, 1998).

According to the report of the State Committee on Overseas Vietnamese Affairs, 4.5 million Vietnamese people are living and learning in 103 foreign countries (Nam Phong, 2012). Among them there are many Cao Dai believers. In our estimation in the foreign countries there are about 50.000 Cao Dai followers. They are mainly living in America, Canada, Australia and France.

In foreign countries, Cao Dai believers organize religious activities, they build temples, furthermore, many new Cao Dai sects are established for example, Thien Ly Buu Toa sect in San Jose city, America. And, they have also many relationships with Cao Dao followers in Viet Nam.

\section{Literature Reviews}

In recent years, study of Cao Dai followers abroad has some books and articles, such as Sergei Blagov's Cao Dai book published in 2001 and republished by Cao Dai Overseas Missionary in 2017, added Cao Dai section after 1975 into the book, especially chapter 14 added with title "Diaspora and Foreign Mission after 1975". This chapter deals emergence of Cao Dai religion abroad, particularly in the United States after 1975; which mentions establishment of Caodaism organizations in the United States as Thien Ly Buu Toa in San Jose, California; Cao Đài Overseas of Do Van Ly in Southern California (1990); Cao Đài Center in Anaheim, California was created by Bùi Đắc Hùm in $2014 \ldots$ In this book, Sergei Blagov has also statistics, there are 22 worship sites of Caodaism in the United States, and the number of followers in the United States is 
about 20,000 people (Sergei Blagov (2017). Book of The Divine Eye and the Diaspora by Janet Alison Hoskins, published in 2015, also mentions the rise of Caodaism in the United States since 1975. In it, political events in the South of Vietnam in 1975, especially, the collapse of the Republic of Vietnam's Government and migration of the South people to the United States and other countries were mentioned.

Migration of the South people was mentioned as an important event to impact on development of the number of Cao Dai followers overseas, specifically in America. Caodaism's followers also merged in that influx of immigrants, settled in America, and developed their religion. Cao Daists such as Do Van Ly, Bui Van Kham, Tran Quang Canh, Bui Dac Hum... are mentioned in the book as evidences for development of Cao Dai religion in America, specifically in California. Especially, the character of Tran Quang Canh is mentioned as one of Cao Dai important followers created a good relationship between Tay Ninh Cao Dai Holy See and Cao Dai followers in America, as so as the relationship between Cao Daists in the United States with theologic organizations in the world; Center Spirite Lyonnais Allan Kardec is a prime example. An article of Jérémy Jammes is "Caodaism and its Global Networks: An Ethnological Analysis of a Vietnamese Religious Movement in Vietnam and abroad" in Moussons on Vietnam: Histoire et Perspectives Contemporaneity, No. 13-14, 2009, also mentions Cao dai followers in the United States and the role of Tran Quang Canh in promoting Caodaism with overseas scientific organizations by participating in international religious conferences, also establishment of Cao Dai Overseas Missionary of Mr. Tran Quang Canh in America also mentioned in the article. In general, the books and articles dealt with the relationship between Caodaism abroad with Cao Dai religion in Vietnam, but mention co-ordinated relationship, and explain appearance and distribution of Cao Dai followers overseas, especially in the US. There is no deep mention of the mutual relationship, as well as conflict relation between Cao Dai in Vietnam and Cao Dai followers abroad in recent years. Therefore, study of this article can be considered as a new topic to the present.

\section{Methods}

In order to have data sources to write this article, we had to do fieldwork in the United States in 2009, specifically, at Westminster temple, Anaheim, temple, California temple, and Thien Ly Buu Toa temple. In Vietnam, our colleagues and we did some research methods such as participant-observation, depth-interview at Cao Dai temples church in the Mekong Delta in 2016. 


\section{Results}

\subsection{Cao Dai followers in foreign countries: the process of establishment and development after 1975.}

According to insufficient statistics, 48 Cao Dai establishments are built in foreign countries nowadays, including: 30 establishments in America, 5 establishments in Canada, 7 establishments in Australia, 3 establishments in France... Most Cao Dai believers in foreign countries are emigrants. These establishments are built with different models. Many temples are modeled on Tay Ninh Holy See, for example Cao Dai temple of New South Wales in Sydney, Australia. It was opened for public use on $18^{\text {th }}$ November, 2000; the Cao Dai temple of New Orleans in Louisiana was inaugurated on $25^{\text {th }}$ November, 2006; the Cao Dai temple of Cali in Orangewood city, Cali was opened on $23^{\text {rd }}$ December, 2007; the temple of Wichita in Kansas was opened on $5^{\text {th }}$ September, 2010; the temple of Dallas Fort Worth in Texas was opened on $3^{\text {rd }}$ October, 2009 and the temple of Houston in Texas was opened on $6^{\text {th }}$ September, 2015... Other temples were former houses which were bought and renovated by Cao Dai followers (followers of Caodaism) so their architectures are different each other.

The activities of Cao Dai followers in foreign countries in general and in America in particular have based on the principle without discrimination of sect origins. In fact, we know that there is separation in gathering of Caodaists. In California there are 8 temples, 2 shrines as following: the temple of California, the temple of Orange County, the temple of Westminster, the temple of Garden Grove, the temple of Anaheim; the temple of Pomona; the temple of San Diego; the temple of San Jose. Two shrines are the shrine of Orange County and the shrine San Jose, Cao Dai followers who practise their religious activities in these temples and shrines are believers originating from Tay Ninh Holly See. Cao Dai followers of other sects practise their religious activities in the temple of Anaheim. Cao Dai followers who are former soldiers of the government of Republic of Vietnam often go to the temple of Westminister.

Although there is separation in gathering of Cao Dai followers, all Cao Dai followers preserve and maintain the "New Canonical Codes" and the "Religious Constitution of the Caodai Religion". Because of many reasons such as view of politics, the view of religious practice, Cao Dai followers often choose temple to practise. In fact, they can implement religious practice in different temples but dignitaries are not flexible as believers because they have to fulfill their duties in the temple where they take charge

Besides rites, Cao Dai followers in America as well as in other countries take part in other social activities. They establish Dai Dao Thanh nien hoi (organization of young people) in Cali. Young believers like to take part in this organization. This organization also cooperates with organizations of other religions to promote national culture. Cao Dai followers take part in charitable activities. 
Many Cao Dai followers participate in teaching Vietnamese language to children. Teaching Vietnamese language is one of many religious activities because Cao Dai followers would like to maintain mother tongue and Vietnamese culture. In the temple of San Jose and other temple there are Vietnamese classrooms

In order to propagate and develop Cao Dai church, Cao Dai followers of Tay Ninh Holy See in America has established Oversea Missionary on $5^{\text {th }}$ September, 1998. Mr. Tran Quang Canh was elected chairman of representative of Oversea missionary. This organization can represent Cao Dai communities in foreign countries in getting touch with scientists and other religions. Believers who take part in $3^{\text {rd }}$ Meeting of Cao Dai followers in Montreal agreed on establishment of the Oversea Missionary. This organization is independent one, it is not directly under any Cao Dai sect in Vietnam. This organization is a bridge between Cao Dai followers in many countries. Mr Tran Quang Vinh is the head of this organization. According to Mr Tran Quang Vinh, the main aim of establishment of Oversea Missionary is to develop Caodaism in foreign countries. In foreign countries, Cao Dai followers who understand deeply Caodaism are old. They have not able to explain Cao Dai's dogmas to international scientists and politicians in foreign languages. Young Cao Dai followers are very good at foreign languages but they have not a thorough knowledge of Caodaism. That is why Oversea Missionary can't operate well. At the Conference on Religions in the World in VDH Bryn Athyn, Philadelphia America in 1999, Cao Dai followers (delegation consists of Mr. Tran Quang Canh, Mrs Nguyen Ngoc Lan Mr. La Van Luc, Mr. Le Van Co..) have not able to report dogmas of Cao Dai in English so Dr. Sergei Blagov and Ma. Christopher Hartney had to help them. Taking part in this Conference was the first act of Oversea Missionary in introducing Caodaism to foreign countries. According to the report of Oversea Missionary, after Conference many international researchers studied Caodaism such as Doctor Massimo Introvigne (Italy) Professor Dan Fefferman (Washington DC). After this Conference, Oversea Missionary met Professors and students of well-known universities in the world. Allan Kardec Center of Spiritualism in Lyon, France invited Oversea Missionary to talk on Caodaism in March, 2004

In generally, Oversea Missionary has significant contributions in propagating Caodaism to foreign countries but it is directly under Cao Dai Church in Vietnam so it can't help foreign scientists when they request to contact with Cao Dai Church in Vietnam. So Mr. Tran Quang Canh returned to Vietnam and contacted with Holly See in Tay Ninh. Holly See in Tay Ninh accepted him.

After returning to Vietnam Mr. Tran Quang Canh continuously undertook Oversea Missionary. Since then Holy See in Tay Ninh has patronized Oversea Missionary. On $31^{\text {st }}$ August, 2015 Holy See in Tay Ninh promulgated instruction no 369/90- NCPSHL on appointment of Mr. Tran Quang Canh to be chief representative of Cao Dai Church 
in foreign countries. Since then Oversea Missionary has become Representative organization of Cao Dai church in foreign countries. Both Vietnamese and American Governments recognize this organization. Its international name is Cao Dai Overseas Missionary. The duty of Cao Dai Oversea Missionary is to propagate Caodaism in foreign countries under many different forms such as Cao Dai representatives can take part in International Seminar on religion. They can help scientists, tourists who would like to study Caodaism.

The important result of Cao Dai Overseas Missionary in propagating Caodaism in foreign countries is that subject on Caodaism is taught in Dhaka University in Bangladesh and Vienna University in Austria. Dhaka University in Bangladesh awards MA and Ph.D in Caodaism.

After 1975, Caodaism was present in foreign countries because many Cao Dai followers emigrated and live foreign countries. Cao Dai followers in foreign countries belonged to different sects. They operated independently and not to relate to Cao Dai church in country. They set up new churches

Many propagandic organizations are established in foreign countries but they are not orthodox organizations so that the oversea representative organization of Holy See in Tay Ninh was born. This organization has been directly under Cao Dai church in Tay Ninh.

The official oversea organizations of Caodaism in foreign countries often connect with Cao Dai church in Tay Ninh. The other Cao Dai sects do not govern their believers who are living in foreign countries. Cao Dai followers who not belong to Cao Dai Church in Tay Ninh often operate independently their religious orientation is different from the view of Cao Dai Church in country and Government.

\subsection{The administrative relation between Cao Dai followers in foreign countries and} Cao Dai church in country: mutual aid and conflict

The mutual aid in administrative relation

As you know, after 1975 many Vietnamese Cao Dai followers emigrated to foreign countries, they were believers of different Cao Dai sects, Because of many reasons they left Vietnam for other countries, one of these reasons is the political reason that was why they had not sympathy for events which happened in our country. They operated religious activities independently and they had not friendly relation with Cao Dai church in country, especially when the open-door policy of State was not implemented.

Since 1990s, the diplomatic policy of Vietnam has changed and our economy has gradually developed. Many foreign companies have invested in Vietnam, the traveling between Vietnam and other countries is fairly easy. So the relation between Viet Nam people abroad and at home has become close, The relation between Cao Dai church in country and Cao Dai followers abroad is better. The dignitaries of Cao Dai church, 
especially dignitaries of Cao Dai church in Tay Ninh have invited Cao Dai followers who live in America to visit and talk about the situation of Caodaism in America as well as in Cambodia, Korea, Japan...

Thanks to the open-door policy of Vietnam, many Cao Dai followers in foreign countries have opportunity to take part in Cao Dai activities in country. They co-operate with Cao Dai church in country to propagate Caodaism in foreign countries. Especially, Cao Dai followers who come from Holy See of Tay Ninh actively take part in developing Caodaism in foreign countries. Many of them are nominated as important positions of Cao Dai church in foreign countries. Some of them return Vietnam and serve Holly See

This is the result of the mutual aid in administrative relation between Cao Dai church in country and Cao Dai followers of Tay Ninh Holy See in foreign countries. Cao Dai followers of other sects in foreign countries have hardly mutual aid of their sects in country. Dignitaries of their sects in country are not interested in creating the relation between their sect and their believers in foreign countries.

When mentioning the mutual aid we should talk about printing and propagation of books, law, rule of Caodaism so Cao Dai followers who are living in foreign countries can read many articles books of Cao Dai intellectuals. After over 40 years, the administrative relation between Cao Dai followers in foreign countries and Cao Dai church in country have active changes. Besides, this result is conflicts.

The conflict in administrative relation.

Cao Dai church in country conflicts with a small part of Cao Dai followers in foreign countries. The reason of conflict is divergence in politics. After 1975 many Cao Dai followers emigrated to foreign countries. Because of many reasons they left Vietnam for other countries, one of these reasons is the political reason. Because of different views there is contradiction in administrative relation between Tay Ninh Holy See and Cao Dai followers in foreign countries. The regulation of organizational structure of Cao Dai church in Tay Ninh has lasted this contradiction.

On $1^{\text {st }}$ March, 1979, the instruction 01 was promulgated. It also mentioned in dissolution of the administrative structure of Cao Dai church. The Executive Power, the Legislative Body, Charity Section and other sections were dissolved. The Management Council replaced above sections. The Management Council has been the standing organization of Cao Dai church. The Management Council has a strong attachment to the Vietnam Fatherland Front. This Council executes seriously line and policies of Party. This Council encourages all believers to take part in the cause of building and defending our country. 
Some problems are mentioned in Instruction no 01 and some rules of the Management Council make some Cao Dai followers in foreign countries uncomfortable. They protest Cao Dai church in country and think that modification is contrary to traditional rules of Caodaism. They declare that they do not comply with the Management Council and they call Cao Dai communities in foreign countries to "defend traditional rules of Caodaism".

In fact, not only Cao Dai church in Tay Ninh has the Management Council but also other Cao Dai churches have one. But the other Cao Dai churches do not proclaim to dissolve administrative structures. So Instruction 01 is the important reason of disharmony between some Cao Dai followers in foreign countries and Cao Dai church in Tay Ninh. However, the Management Council still have existed. It manages Cao Dai church according to the rules of the Democratic Republic of Vietnam. Basing on New Charter that was proclaimed on $5^{\text {th }}$ April, 1997, the Management Council is operating agency of Cao Dai church in Tay Ninh. It is directly under Cao Dai Church. According to New Charter, Cao Dai church is governing body to manage all religious acts, rules, laws, rites of the Great way of the third universal salvation. Cao Dai Church has right to supervise all acts of the Management Council. According to New Charter, Charity Section undertakes food production and takes part in charitable activities.

According the New Charter 1997 the Management Council is not the most powerful council. Its acts are supervised by Cao Dai Church.

According to New Charter that was proclaim on $5^{\text {th }}$ December 2007. The Management Council was dissolved. Cao Dai Church has operated church. According to this Charter, administrative mechanism of Cao Dai Church in Tay Ninh has changes. Executive Power and the Legislative power have been restored. But Cao Dai followers in foreign countries have not satisfied with changes of Cao Dai church of Tay Ninh. They continuously oppose Cao Dai Church in Tay Ninh. Their oppositions are often expressed in writings, on website. They call others to oppose Cao Dai Oversea Missionary. Their opposition brings about bad effects on the administrative relation between Cao Dai church in country and Cao Dai followers in foreign countries. The contradiction has not great influence on the development of Cao Dai Church in general and Cao Dai Church in Tay Ninh in particular. The contradiction can be seen as "reflecting minor". It helps Cao Dai church to correct itself.

As already analyzed, in recent years, the administrative relation Cao Dai Church in general, Cao Dai Church in Tay Ninh in particular and Cao Dai followers in foreign countries has expressed in two trends: "cooperation" and "conflict". The co-operation is the main element to develop Caodaism. But conflict is also the element to help Cao Dai church to correct itself. If we look the conflict in negative angle, we find that Cao Dai Church has met many difficulties. It may be dissolved because many sects and Cao 
Dai followers are against each other. In the active angle, the opposition helps Cao Dai Church to correct itself, such as its Charter has some changes during 20 years.

According to us the political reason also creates conflict in the relation between Cao Dai Church and Cao Dai followers in foreign countries. Because of political reason, many Cao Dai followers emigrated and lived in foreign countries. They often oppose Sate. They take advantage of religion to protest policies of State. They spread rumors that Cao Dai Church in country as "religion of State" because State can intervenes in Cao Dai Church's affairs; in Vietnam there is not freedom of religions and belief. The political difference leads to religious difference. This matter expresses clearly the opposition of Cao Dai followers in foreign countries to Cao Dai Church in Tay Ninh. The conflict also takes place silently in Cao Dai churches. Many Holy Houses or Oratories do not listen to Cao Dai Church. This secession is due to internal difference. It does not relate to political element and the change of administrative mechanism. This difference is different from the conflict that we have just mentioned

\section{Discussion}

After 1975, the political view of Cao Dai followers who emigrated to foreign countries is different from the political view of our Sate. The difference also expresses clearly in the conflict between small part of Cao Dai followers in foreign countries and Cao Dai church in country.

In the past some policies of the Democratic Republic of Vietnam on religion and belief were not logical. In 1990 the Politburo proclaimed Resolution No 24/NQ- TW on Belief and Religion with new recognition: 1) Religions is long-standing problem; 2) Religion and belief are spiritual needs of a segment of the population; 3) Religious ethics has some aspects in accordance with the cause of building new society. Since then our State recognizes that religious affairs not only take interest in logic needs of religion and belief of people and but also timely struggle against enemies who take advantage of religion to destroy revolution. The main content of religious affairs is to mobilize the masses. Religious affairs are the responsibility of the entire political system (Nguyễn Đức Lữ, 2015). After Resolution No 24/NQ-TW, the Ordinance on Belief and Religion came into the world. The religious affairs are strengthened the right to freedom of belief and religion is highly appreciated.

Not only small part of Cao Dai followers in foreign countries but also some followers of other religions think that Vietnam has not the freedom of religion and belief. However, the active adjustment of Vietnamese government has resolved many problems on religious and political differences so the contradiction of Cao Dai 
followers in foreign countries and Cao Dai Church in country has gradually been solved. Many Cao Dai dignitaries in foreign countries return country. They also take part in all activities of Cao Dai Church in country.

In general, the administrative relation of Cao Dai followers in foreign countries and Cao Dai Church in our country follows two different tendencies: mutual aid and conflict. The reason of conflict is difference on political view. In order to minimize conflicts in the administrative relations of Cao Dai religion, it is necessary to have specific solutions to be proposed. There are:

- For Cao Dai church in general and Cao Dai church in Tay Ninh in particular: Cao Dai Church has to develop young dignitaries who are good at foreign languages and well -informed about history, laws, rules of Caodaism. They can participate in meeting, seminar on religion in the world. The can lecture others about Caodaism. At first, this task will meet many difficulties, especially resistance of old Cao Dai followers. Then all difficulties will be resolved.

- For government: government should have more diplomatic activities with Vietnamese communities and Cao Dai followers in foreign countries. Government should rectify the rumors on policies of State as well as religious policy. In fact, people living in foreign countries who oppose State do not understand situation of country clearly. The only know news what are propagandized by unofficial means of communications abroad and at home. So State should directly get in touch with Vietnamese communities in foreign countries and help them to understand renovation and development of Vietnamese more and more

State should get into conversations with religious believers in general and Caodai followers in particular. The nature of religious conflict is the political difference. This difference can't be resolved by rigid measures. It can be resolved by dialogues of both sides. We should consider religion as a part of human society and religion is not separate from society; Its function and role are similar to function and role of other components in society. Religion only changes not to disappear, so religion can't be annulled in society. The religious conflict in Cao Dai church because Cao Dai followers in foreign counties have not understood Vietnamese policies clearly. They think any religion which has operated freely is religion of State. That is why they consider Cao Dai Church in country in general and Cao Dai Church in Tay Ninh in particular as the religion of State because these organizations operate freely, the number of their believers is developing, their festivals are performed openly. The dialogues between State and Caodiasts in foreign countries help Cao Dai followers understand policies of State on freedom of belief and religion. However, these resolutions are not realized right away. We should have logical solution to each matter. 


\section{Conclusion}

The relationship between the Cao Dai religion in Vietnam and the Cao Dai followers abroad has been manifested right from the beginning of this religion spreading abroad. However, depending on each period of history, this relationship has different changes. Prior to 1975, the relationship between domestic Cao Dai institutions and Cao Dai followers abroad was largely based on religious affiliation and development, without any significant conflict or opposition. But since 1975, because of diplomatic policies of the Socialist Republic of Vietnam and the Western word where most of foreign Cao Dai followers immigrated, political conflicts emerged thus leading to opposition. This opposition also affects a group of anti-communist domestic followers and resulted in instability. However, this has not negatively impacted on the development of the Cao Dai religion, especially in the progress of relations with Cao Dai overseas. These relationships can be seen as a good development of Caodaism in the South of Vietnam during the period of international integration. Therefore, Caodaism has attracted many domestic and foreign scholars' researches, with the presence of some Cao Dai dignitaries in World Religions Conferences in recent years. In general, the external connections of Caodaism in the South have been taking place in many different directions due to the influence of many factors. In particular, the political, cultural issues can be deemed as the main factors that affect on these relationships. Depending on the factors involved, there will be different relationship including not only integration, association, mutual assistance ... but also conflict and instability. This basically also reveals the practice of Caodaism in Vietnam nowadays.

\section{Acknowledgements}

This article was originally submitted to the International Conference on Religion Studies in Viet Nam organized by the Institute of Religion Studies, Vietnam Academy of Social Sciences in November 2017. After being presented at the conference, it was commented by the scientists studying religion and ethnicity attending the conference, and then I revised it according to those comments so that it becomes this complete article.

\section{References}

Blagov, Sergie (1999) Caodaism, Global Ambition vs Persecution. A peper presented at CESNUR 99 conference, Bryn Athyn, Pennsylvania. http://www.cesnu.org/testi.bryn.brblagov. htm (access on 25th March, 2005)

Hesselgrave, David J, [Editor], (1978), Dynamic religious movements: case studies of rapidly growing religious around the world [Book] Grand Rapids: Baker Book House. 
Hoa Nhan (1967) 40 Historical years of the Great way of the third universal salvation (Caodaism), http://wwwpersonal .usyd.edu.au/ cdao/booksv (access om 25 ${ }^{\text {th }}$ October, 2015)

Huynh Ngoc Thu \& Nguyen Phuoc Tai (2019). "The Relationships Between Cao Dai Religion in Vietnam and Cao Dai's Overseas Followers in Recent Years", Frontiers of Daoist Studies, Volume 4 June 2019, ISSN 2312-2250

Nam Phong (2012) “Hơn 4,5 triệu nguoòi Việt sống ỏ nước ngoài" Vietnam net. Htt://vietnamnet.vn/vn/thoi-su/90272/hon-4-5-trieu-nguoi-viet-song-o-nươc-ngoai.html (access o $1^{\text {st }}$ September, 2015).

Ngọc Mỹ Thanh (1960) Cẩm nang hành chánh đạo. Tòa thánh Tây Ninh. http://ww. Personal.usyd.edu.au/cdao/booksv/pccs.htm (access on $20^{\text {th }}$ October, 2013)

Nguyễn Đức Lữ (2015) Vấn đề tôn giáo tù Đại hội đến Đại hội của Đảng trongthời kỳ đổi mói"” http;//btgcp.gov.vn/Plus.aspx/vi/News/38/0/240/0/2000/vandetongiaotuDai hoi den Dai hoi của Dang trong thoi ky doi moi (access on $25^{\text {th }}$ March, 2016)

Nguyễn Thanh Xuân (2005) Một số tôn giáo ở Vietnam (Some Vreligión in Vietnam). Religin Publishing House

Robison,W. Courtland (1998) “Terms of Refuge”; London: Zen Books, Ltd, 1998 p 173-175

The Government Committee for Religious Affairs (2007),The legal documents on Belief and Religions, Religion Publishing House, $\mathrm{H}$

Trần Duy Nghĩa (1974) Chánh trị đạo, http;//ww.Caodaism.org/home.htm (access on $20^{\text {th }}$ May .2014)

Võ Kim Quyên (1973). Tôn giáo và đời sống hiện đại (Religions and Modern life), vol. 1, 2 Social Science Publishing House

Werner. S. Jayne (1981) Peasant Politics and Religious Sectarianism. Peasant and priest in the Cao Dai in Vietnam. Monograph Series No 23, Yale University Southeast Asan Studies 